\title{
Drug utilisation in a public health perspective: Establishing a national prescription register in Norway
}

\author{
Kari Furu \\ Senior adviser, Royal Ministry of Health and Social Affairs, Oslo, and research fellow, Institute of General \\ Practice and Community Medicine, University of Oslo, Norway \\ Correspondence to: Kari Furu, Ministry of Health and Social Affairs, Department of Health, P.O. Box 8011 Dep, NO-0030 Oslo, Norway \\ Telephone: +47 22248713 Telefax: +47 22249578 E-mail: kari.furu@shd.dep.no
}

\begin{abstract}
No information about drug use at an individual level is available from the present Norwegian wholesale statistics on drugs, i.e. who are using the medicines, for how long and in which doses. A new kind of statistics is needed to focus on and analyse the use of medications from a public health perspective and to evaluate other aspects of public health in relation to drug expenditures. To meet this need, the Ministry of Health and Social Affairs has decided to establish a new national register based on computerised prescriptions from all the pharmacies in Norway. The initiative to establish a more detailed drug statistics came partly in response to changes in the infrastructure of the Norwegian Drug Market, which started when Norway became a member of European Economic Association (EEA), in 1995. To regulate and evaluate the impact of a country's national drug policy with respect to the promotion of the rational use of drugs, it is vital that the system designed to collect data about the consumption of medicines is set up at the level of individual patients. This paper will focus on the planning and the necessary steps to be taken for establishing a national database of drug prescriptions in Norway.
\end{abstract}

\section{INTRODUCTION}

Norway has a long tradition of accurate wholesale statistics on drugs and was the first country to produce public drug statistics in the sixties. From 1977 these figures have been published annually in a book containing complete information about the drug sales in Norway (1). The total sales of drugs in 2000 were about 11.4 billion NOK calculated in pharmacy retail price, and the National Health Service (Rikstrygdeverket) reimbursed about $50 \%$ of the costs. Although highly useful, the figures based on drug sales from wholesalers to pharmacies and hospitals have some limitations. No information about drug use at an individual level is available from the wholesale statistics. Thus, we lack information about who are using the medicines (how many people, age, gender), for how long, and in which doses. Therefore, the Norwegian Ministry of Health and Social Affairs has decided to establish a national register based on computerised prescriptions from all the pharmacies. The proposal to establish a prescription register in Norway has been mentioned in several official documents since 1996 (2-6). In 2000, the author of this article was engaged as a project leader to organise the planning process and make a detailed proposal for this system. This paper will focus on the planning process and the necessary steps to be taken for establishing a national database of drug prescriptions in Norway.

\section{WHY A NATIONAL PRESCRIPTION REGISTER?}

The proposal for a more detailed drug statistics came partly in response to changes in the infrastructure of the drug market, which started when Norway became a member of the European Economic Association (EEA) (Table I). Until 1995, Norway had only one stateowned wholesaler, and this wholesaler had been responsible for all drug statistics since 1970. The monopoly of the wholesaler was removed in 1995 and since then three wholesalers have been active in the Norwegian drug market.

After 1995, relatively more new medicines and chemical entities have been introduced per year to the Norwegian market (Table II). This will inevitably continue to be the case after Norway became a member of the European Agency for the Evaluation of Medicinal Products (EMEA) in January 2000. This implies that new and innovative drugs will be available in Norway at the same time as in other countries in the EU. The marketing of new drugs has been sped up considerably in EU, partly as a consequence of the common EU regulatory system. The US Food and Drug Administration (FDA) has also sped up this process. Some will say the FDA is allowing unsafe drugs onto the market because of its attempt to speed up its decisions, and in 2000 three prescription drugs had to be withdrawn due to lack of safety. Nevertheless, new thera- 
Table I. Some consequences for the Norwegian Drug Market after Norway became a member of the European Economic Association (EEA).

\begin{tabular}{|c|c|c|}
\hline Year & What happened? & Consequences \\
\hline 1995 & Norway became a member of EEA & $\begin{array}{l}\text { The monopoly of the wholesaler was broken. } \\
\text { Free pricing of non-prescription drugs. } \\
\text { The "need clause" (= behovsparagraf) was withdrawn. } \\
\text { This clause may have provided for the limited range of drugs } \\
\text { launched in Norway before } 1995 \text {. }\end{array}$ \\
\hline 1996 & $\begin{array}{l}\text { Report from National Board of Health: } \\
\text { "National prescription-based drug statistics" } \\
\left(15^{\text {th }} \text { July }\right)\end{array}$ & $\begin{array}{l}\text { The Ministry of Health and Social Affairs started the planning } \\
\text { of the national prescription register. This was reflected by } \\
\text { financial support in the National Budget to the planning of the } \\
\text { prescription register. }\end{array}$ \\
\hline 1997 & $\begin{array}{l}\text { Norwegian Official Report No } 61997 . \\
\text { Prerequisites for the sale of medications: } \\
\text { "Cost-effective medications" [In Norwegian]. } \\
\text { Oslo NOU 1997:6. } \\
\text { Norwegian Official Report No } 7 \text { 1997. Pills, } \\
\text { Priorities and politics: What kind of reim- } \\
\text { bursement system is needed for patients and } \\
\text { society? [In Norwegian]. Oslo NOU 1997:7. }\end{array}$ & $\begin{array}{l}\text { Proposals for better and more detailed drug statistics in Norway, } \\
\text { i.e. a prescription register is needed to materialise the principles } \\
\text { behind the national policy in the drug field. }\end{array}$ \\
\hline 1998 & $\begin{array}{l}\text { The Ministry of Health and Social Affairs } \\
\text { sent the report from } 1996 \text { on a general } \\
\text { hearing, involving several concerned parties }\end{array}$ & $\begin{array}{l}\text { A majority of those giving an opinion support the creation of a } \\
\text { prescription-based register. Moreover, several parties stress the } \\
\text { need for information on an individual level (for example Medical } \\
\text { Birth Registry, University of Bergen, Cancer Registry). }\end{array}$ \\
\hline 2000 & $\begin{array}{l}\text { Norway member of the European Agency for } \\
\text { the evaluation of Medicinal Products (EMEA) }\end{array}$ & $\begin{array}{l}\text { Drugs may be introduced to the Norwegian Drug Market at the } \\
\text { same time as in other EU-countries. }\end{array}$ \\
\hline 2001 & $\begin{array}{l}\text { New legislation in the Norwegian Pharmacy } \\
\text { sector ( } 1^{\text {st }} \text { March), new Regular GP Scheme } \\
\left.\text { in the primary health sector ( } 1^{\text {st }} \text { June }\right) \text {, and } \\
\left.\text { new Health Register Act ( } 1^{\text {st } J a n u a r y ~} 2002\right)\end{array}$ & $\begin{array}{l}\text { The drug distribution system is liberalised. International com- } \\
\text { panies may own Norwegian pharmacies. Generic substitution is } \\
\text { introduced. } \\
\text { List patients assigned to doctors: all GPs will be given a fixed list } \\
\text { of citizens (Fastlegereformen). } \\
\text { The new Health Register Act calls on a separate act for } \\
\text { establishing of a Prescription register. }\end{array}$ \\
\hline
\end{tabular}

pies require renewed surveillance systems because the documentation concerning long-term effects and health economic outcomes of a new drug will be scanty at the time of approval.

There are large differences in prescribing patterns between European countries, which cannot be explained by morbidity variations (7). For example, the different utilisation of lipid-lowering drugs in Sweden and Norway raise many important questions (Figure 1). Why do we have such large differences in two neighbouring countries, and what are the consequences in terms of clinical outcomes? Decreased blood levels of cholesterol in the general population? Decreased morbidity or mortality in the population? To answer these kinds of questions, we need information about the drug use at an individual level as well as the possibility to do record-linkage studies. This will enable us to assess the safety and effectiveness of medication use in relation to health outcomes, i.e. from a public health point of view (7).

To regulate and subsequently evaluate the impact of a country's national drug policy for a more rational use of drugs, it is vital that the system designed to collect medicine consumption data is set up at the level of individual patients. Studies of how a drug is actually being used, and identification of determinants for changes in these usage patterns, can only be made after the drug is launched on the market. Despite the complexity of the steps of drug development before marketing, knowledge of its future potential effects in practice is limited. The information gathered by means of randomised controlled clinical trials (RCTs), is concerning efficacy, i.e. the ability of the drug to bring about the intended effect under ideal conditions (e.g. in clinical trials). However, little is known about effectiveness (i.e. the ability of the drug to bring about the intended effect in a normal clinical setting), because the circumstances of clinical practice differ substantially from those of clinical trials. This is true in several respects: number of patients, length of exposure, representativeness of the target population, dosage, drug interactions, and compliance (8). 


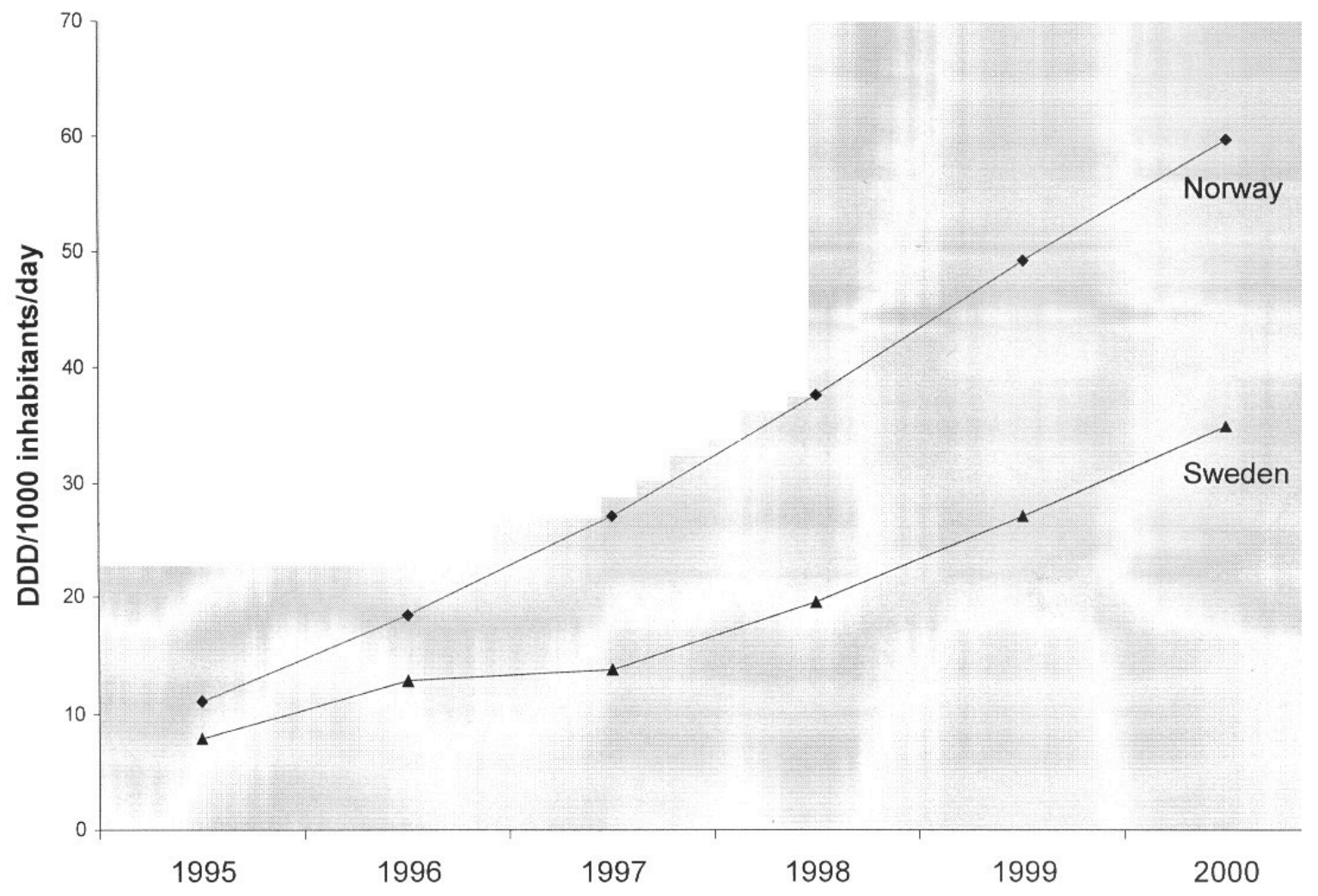

Figure 1. Utilisation of serum-lipid lowering drugs in Sweden and Norway during 1995-2000. Defined Daily Doses per 1000 inhabitants per day sold from pharmacies.

\section{THE OBJECTIVES OF A NATIONAL PRESCRIPTION REGISTER}

Recording data on drug use on an individual basis may provide a new opportunity to investigate the prevalence and incidence of drug use in the Norwegian population. Such information may be valuable in clinical as well as administrative discussions concerning rational use of drugs. Overuse, underuse, polypharmacy etc. may be a threat to the health of the single patient as well as for the population. These aspects can be studied most efficiently by using data from populationbased prescription databases.

The main objective of a prescription register is therefore to improve knowledge of the drug utilisation in the general population after the drug has been marketed in Norway. This can be undertaken by:

- identifying benefits and potential problems to the public health linked to utilisation of given drugs or drug groups.

- assessing the safety and effectiveness of medications, also in relation to health outcomes.

- making drug utilisation data available to the prescribing doctors as part of an audit method to improve the quality of prescribing practices.
- doing health economic analyses, for example on the implementation and compliance of reimbursement decisions.

- developing and validating procedures for collection, analysis and interpretation of drug utilisation data at a national level.

- comparing drug utilisation data from Norway with those of other countries.

Table II. The number of new drugs approved in Norway per year during 1980-2000 (Source: Norwegian Medicinal Drug Agency).

\begin{tabular}{|c|c|c|c|c|}
\hline Year & \multicolumn{2}{|c|}{ New drugs } & \multicolumn{2}{|c|}{ New entities } \\
\hline 1980 & 62 & & & \\
\hline 1990 & 109 & \multirow{6}{*}{$118 /$ year } & 19 & \multirow{6}{*}{ 19/year } \\
\hline 1991 & 97 & & 10 & \\
\hline 1992 & 113 & & 22 & \\
\hline 1993 & 121 & & 16 & \\
\hline 1994 & 128 & & 30 & \\
\hline 1995 & 141 & & 15 & \\
\hline 1996 & 172 & \multirow{5}{*}{ 234/year } & 31 & \multirow{5}{*}{$41 /$ year } \\
\hline 1997 & 253 & & 46 & \\
\hline 1998 & 215 & & 36 & \\
\hline 1999 & 244 & & 34 & \\
\hline 2000 & 295 & & 56 & \\
\hline
\end{tabular}


Prescribing drugs is an important part of the national health care, and about $60 \%$ of the consultations with a Norwegian general practitioner (GP) result in a prescription being issued. A feedback system to general practitioners based on the national prescription register has been practiced in Denmark for several years (9). Last year, small groups of Norwegian general practitioners received feedback about their own prescribing patterns in order to evaluate and compare the prescribing. This pilot-project was carried out to show how GPs could benefit from data from a new national prescription database (10). The GPs have been very satisfied with the possibility of discussing their own prescribing with colleagues $(9,10)$. Pharmacoepidemiologic evaluations, if done properly, will lead to safer use of medicines and the public will probably benefit from this type of research.

\section{DATA SOURCES}

New legislation in the Norwegian pharmacy sector entered into force on March $1^{\text {st }} 2001$, making Norway the second Nordic country to liberalise its drug distribution system (5). In 2000, about 20 million prescriptions were handled by the approximately 400 pharmacies in Norway. During the past ten years, the Norwegian retail pharmacies have computerised the handling of prescriptions. According to the new act, they may be urged to forward data to a new national drug database. This will include all prescriptions (reimbursed or not) and drugs sold to hospitals and nursing homes. Figures for over-the-counter medications will only be collected from the wholesalers. The wholesalers must also deliver data to the new register on their total sales of drugs, but this will not be at an individual level and will therefore not be discussed any further in this paper.

The following prescription data will be provided by the pharmacies:

- Date, time and place for the handling of the prescription

- Prescribing doctor, dentist, veterinary (unique identification number)

- Patients: 11 digits unique civil registration number ("fødselsnummer"), sex, age

- Drug: Unique Nordic article number, number of packages, possibly generic substitution, total price, patient share, reimbursements, ATC code and DDD

- Reimbursement code (in some cases this is the equivalent to a diagnosis)

- Code identifying the dispensing pharmacy

Due to the methodological issues involved, the Ministry of Health and Social Affairs will prepare standards for the data that pharmacies will have to provide for the national prescription database. It is crucial to secure a unique identification of patients, prescribers and drugs $(11,12)$. The pharmacies are today already recording most of the data that will be required. Both doctors and pharmacies have permissions from the Norwegian Data Inspectorate to use the civil registration number in their electronic systems. However, the pharmacies presently only record the patient's name, address, and the date of birth because it has not yet been any official demand to record the civil registration number on prescriptions. The use of the patient's civil registration number to secure unique identification of the individual is also recommended in the report from Rogaland Research, because this may prevent misclassifications of individuals (11).

\section{CONFIDENTIALITY ISSUES}

Rapid changes in law, technology, and society are reshaping the way identifiable information about patients is handled. Protection of the privacy of personal health records is an issue of concern to most people, including those who conduct research to benefit the public's health. In Norway, the new Health Register Act will enter into force in 2002 (13). This new legislation embraces the principle of protecting the confidentiality of individually identifiable medical information. One consequence of the new act is that all new registers including person-identifiable data, like the national prescription register, will need a separate act to be adopted by the Norwegian Parliament (Stortinget). A requirement for anonymity of data, as well as informed consent from all individuals to use identifiable data about them would, however, jeopardise the methodological integrity of both research and audit. This would not just hinder the progress of medical knowledge, but may also lead to completely incorrect conclusions due to lack of representativity of data (12, 14). Sweden has assessed the possibilities of obtaining informed consent from each individual patient in order to use their civil registration number in a central prescription database. Their conclusion is that this will not work in a clinical reality. It will disturb the consultation between the GP and the patient, and it will be too time consuming (15). In preparing new legislation, it is therefore important to balance the individuals' interest for privacy with society's need for sound information on medical and public health issues $(16,17)$.

\section{SOURCES OF INSPIRATION}

There are many places to learn, and other countries are some of the best places to learn. During the 1990's, other Nordic countries have established prescription databases. Denmark has been the major source of inspiration in preparing for a national prescription statistics in Norway. Already in 1990 and 1992, two regional databases including all reimbursed medications were established in Odense and Aarhus. The register data are available for research purposes only and the registers are situated at the universities (12). In 
1994, a national register of drug statistics was established at the Danish Medicines Agency. This register includes all drugs sold from the pharmacies (also nonreimbursed drugs) and the information on prescription drugs is available at the level of the individual patient. The purpose is primarily to improve background information in the field of drug utilisation to provide better management and planning, but the data has also been used for specific research projects. The Finnish database on drug utilisation includes all reimbursed medications and was established in 1994 (18). One particular feature with the Danish and Finnish pharmacoepidemiological databases is that they are populationbased and include unique person identifying codes which makes it possible to identify all prescriptions over time for individual patients. This opens up for a new dimension in pharmacoepidemiological research, like doing longitudinal studies and record-linkage with other health data registers, for example medical birth registers and cancer registers. The research undertaken by the Danish databases have shown that the included person identifying code is a prerequisite for clinically relevant and valuable research. In contrast, the national prescription database in Sweden established in 1997, does not include a personal identifying code because of confidentiality issues. In December 2000, the National Health of Board in Sweden concluded that they unfortunately could not do important studies on the uses of drugs because of the lack of the unique personal identifier (19):

"The National Board of Health and Welfare currently lacks the necessary conditions to fulfil the assignment that the Board was commissioned to do in the bill 1996/97:27, Medication subventions and supplies of medication, etc. The reason for this is that the medical products register in the Swedish health system does not contain information that identifies individuals, e.g. civic registration numbers. This means that epidemiological studies on the effects and side effects of medication cannot be conducted. Furthermore, comparisons of the proportion of the population using certain medication in different parts of Sweden and at different times cannot be made, and neither can follow-ups of use of medication, seen from a social or financial perspective, as links to other information are lacking."

Researchers in Denmark have performed recordlinkage studies by using a prescription database together with the Medical Birth registry, to examine the risk of malformations and impaired foetal growth in pregnant women treated with particular drugs (20). The Medical Birth Registry (MBR) in Norway has scarce information about drugs used during the pregnancies, even though MBR was established in 1967 in the wake of the drug catastrophe of thalidomide. Research in this field could be one possible application of the Norwegian prescription database in the future.

\section{CONCLUSIONS}

In the future it will be important to focus on and analyse the use of medications from a public health perspective and to evaluate other aspects of public health in relation to drug expenditures. The recommended prescription register in Norway will cover the entire nation, 4.5 million inhabitants, and it will clearly offer unique possibilities for research and a better knowledge base for national decision-making in the field of drug utilisation. It will include all drugs prescribed to patients outside hospitals by physicians, dentists and veterinarians. The new Health Register Act calls for a separate Act for establishing a Prescription Register. After a general hearing among all the concerned parties, the proposal for a new prescription register will finally be handled by the politicians in the Norwegian Parliament. The intention is to establish the register in 2002.

\section{REFERENCES}

1. Rønning M. Drug Consumption in Norway 1996-2000. Oslo: WHO Collaborating Centre for Drug Statistics Methodology, 2001.

2. Myhr K. Utvikling av nasjonal reseptbasert legemiddelstatistikk. Oslo: Statens helsetilsyn. Rapport utarbeidet på oppdrag fra Sosial- og helsedepartementet, 1996.

3. Norwegian Official Report No 6 1997. Prerequisites for the sale of medications: "Cost-effective medications" [In Norwegian]. Oslo NOU 1997:6.

4. Norwegian Official Report No 7 1997. Pills, priorities and politics: What kind of reimbursement system is needed for patients and society? [In Norwegian]. Oslo NOU 1997:7.

5. Ot.prp. nr. 29 (1998-99) :Om lov om apotek (apotekloven). Ny apoteklov som ledd i en samlet gjennomgang av legemiddelpolitikken. Sosial- og helsedepartementet, 2000.

6. The Norwegian Plan of Action to Combat Resistance to Antibiotics (In Norwegian). Regjeringens tiltaksplan for å motvirke antibiotikaresistens (2000-2004). The Ministry of Health and Social Affairs. Oslo, Norway, March 2000.

7. Medicinal Products and Public Health. European Conference, Lisbon 11.-12. April, 2000. Proceedings and conclusions of the conference. May 2000.

8. Strom B, ed. Pharmacoepidemiology, $3^{\text {rd }}$ edn. Chrichester: John Wiley \& Sons, 2000. 
9. Vægter K. LOMAP-projektet (LægemiddelOrdinationsMønstret i Almen Praksis). En projektevaluering oktober 1999. Storstrøms amt, Sundhedsforvaltningen, Danmark.

10. Kjosavik SR, Gjefsen T. Et konsept for kvalitetsutvikling i allmennpraksis med utgangspunkt i en sentral reseptbasert legemiddeldatabase. Rapport fra Rogalandsforskning på oppdrag fra Sosial- og helsedepartementet. RF-2000/291. Desember 2000.

11. Kjosavik SR, Lone A, Gjefsen T. Krav til datakvalitet i en reseptbasert legemiddeldatabase. Rapport fra Rogalandsforskning på oppdrag fra Sosial- og helsedepartementet. RF-2000/290. Desember 2000.

12. Gaist D, Sørensen HT, Hallas J. The Danish prescription registries. Dan Med Bull 1997; 44: 445-8.

13. Ot.prp. nr. 5 (1999-2000): Om lov om helseregistre og behandling av helseopplysninger (helseregisterloven). Sosial- og helsedepartementet. Vedtatt april 2001.

14. Al-Shahi R, Warlow C. Using patient-identifiable data for observational research and audit. Overprotection could damage the public interest. BMJ 2000; 321: 1031-2.

15. Claesson CB. Läkemedelsreformen och den kliniske vardagen. Redovisning av ett pilotförsök i Landstinget Blekinge. Socialstyrelsen 1998-00-056. Sverige.

16. Vandenbroucke JP. Maintaining privacy and the health of the public. Should not be seen as in opposition. $B M J$ 1998; 316: 1331-2.

17. Data privacy, medical record confidentiality, and research in the interest of public health. International Society for Pharmacoepidemiology. Report 18th August 1997.

18. Klaukka T. The Finnish Database on drug utilisation. Nor J Epidemiol 2001: 11: 19-22.

19. Läkemedelsreformen 1997 - hur blev det? Medical Products Reform 1997 - what results did it produce? [English summary] Stockholm: Socialstyrelsen, 2000-15-007. (http://www.sos.se/SOS/PUBL/REFERENG/ 0015007E.htm).

20. Fonager K, Larsen H, Pedersen L, Sørensen HT. Birth outcomes in women exposed to anticonvulsant drugs. Acta Neurol Scand 2000; 101: 289-94. 